\title{
Aplikasi Formulir KTP Di Kantor Camat Rantau Utara Berbasis Android
}

\author{
Selvi Silestian *, Sumitro Sarkum**, Iwan Purnama** \\ * Manajemen Informatika, Yayasan Universitas Labuhan Batu \\ ** AMIK (Akademi Manajemen Informatika Komputer) Yayasan Universitas Labuhan Batu
}

\begin{tabular}{ll}
\hline \hline Article Info & ABSTRACT \\
\cline { 2 - 3 } Article history: & Pembuatan aplikasi KTP berbasis android ini bertujuan untuk: 1) \\
Received Jul $18^{\text {th }}, 2018$ & Memberikan kemudahan bagi masyarakat dalam mengisi formulir \\
Revised Sep $20^{\text {th }}, 2018$ & KTP tanpa harus datang ke formulir permintaan kantor karena dapat \\
Accepted Jan $26^{\text {th }}, 2019$ & diisi di mana pun mereka menggunakan smartphone; 2) \\
& Mempercepat proses layanan dan membuat kartu ID. Metode yang \\
& digunakan waterfall dan pemrograman yang digunakan dalam \\
Keyword: & penulisan Tugas Akhir ini didasarkan pada pemrograman android \\
Aplikasi KTP & menggunakan database mysql untuk pembuatan skrip php. Dalam \\
Android & aplikasi ini diperlukan fasilitas internet atau wifi dari sebuah ponsel, \\
& yang mana aplikasi tersebut dapat berjalan jika aplikasi tersebut \\
& sudah terpasang terkoneksi di ponsel dalam suatu jaringan. Dari \\
& pembahasan mengenai bentuk ID berbasis android dapat disimpulkan \\
& bahwa: 1) Dengan aplikasi formulir berbasis ID Android ini, proses \\
& memasukkan data populasi dapat dilakukan dengan cepat dan efisien \\
& tanpa harus pergi ke kantor untuk mengisi Identitas; 2) Dengan \\
& aplikasi formulir berbasis ID Android ini, layanan dan pembuatan \\
& kartu ID (kartu identitas) dapat lebih mudah dan lebih cepat; 3) \\
& Pemrosesan data populasi pada aplikasi ID berbasis Android ini akan \\
memudahkan proses kerja sehingga dapat meningkatkan kinerja & lembaga nanti; 4) Telah membangun formulir aplikasi ID berbasis \\
Android yang dirancang menggunakan UML (Unified Modeling \\
Language) dan diimplementasikan menggunakan Aplikasi Eclipse \\
untuk Android menggunakan bahasa pemrograman PHP dan MySQL \\
dan untuk basis datanya daring dalam satu jaringan.
\end{tabular}

Copyright @ 2019 STMIK Triguna Dharma. All rights reserved.

First Author

Nama : Selvi Silestian

Manajemen Informatika

AMIK Yayasan Universitas Labuhan Batu

Email: selvisilestian97@gmail.com

\section{PENDAHULUAN}

Perkembangan teknologi informasi yang semakin pesat menimbulkan peralihan sistem kerja dari manual ke era yang digital. Kecanggihan teknologi mampu mengubah cara pandang setiap orang untuk meningkatkan sumber daya manusia (SDM) yang mandiri, kreatif dan mampu bersaing dalam bidang teknologi. Penerapan teknologi informasi (TI) dilingkungan pemerintah mempunyai peranan penting dalam memberikan kemudahan pada berbagai aspek kegiatan pelayanan publik.

Dan untuk mempermudah masyarakat dalam melakukan pengisian formulir diperlukan sebuah aplikasi yang cepat dan efisien. Adapun aplikasi untuk mengatasi fenomena tersebut adalah aplikasi formulir KTP berbasis android. Aplikasi formulir KTP (Kartu Tanda Penduduk) ini merupakan sebuah aplikasi pengisian data penduduk untuk menghasilkan pelayanan yang cepat dan efisien[1].

Penelitian ini dilakukan pada Kantor Camat Rantau Utara untuk mempermudah masyarakat dalam melakukan pengisian formulir KTP (Kartu Tanda Penduduk). Masyarakat yang ingin mengurus KTP (Kartu Tanda Penduduk) tidak harus pergi ke kantor meminta formulir, dapat diisi dimana pun berada menggunakan 
smartphone. Dan dengan adanya aplikasi ini maka dapat mempercepat proses pelayanan dan pembuatan KTP (Kartu Tanda Penduduk).

\section{LANDASAN TEORI}

\subsection{Definisi Aplikasi}

Aplikasi adalah suatu perangkat lunak yang berjalan diatas suatu sistem operasi dimana perangkat lunak terbuat berisi perintah-perintah yang berfungsi untuk melakukan berbagai pekerjaan atau tugas tertentu yang berhubungan dengan pengolahan data[2].

\subsection{Definisi Formulir}

Formulir adalah sebagai bukti terjadinya transaksi bisnis, merekam data transaksi dan media komunikasi antar orang atau bagian atau organisasi[3].

\subsection{Definisi KTP (Kartu Tanda Penduduk)}

KTP (Kartu Tanda Penduduk) merupakan jenis identitas diri yang diakui di Indonesia bagi penduduk yang dianggap sudah dewasa, yaitu minimal berumur 17 tahun atau sudah menikah[4].

1. Fungsi KTP (Kartu Tanda Penduduk)

a. Memberikan kepastian bahwa pemegang KTP terdaftar sebagai WNI yang sah. Kepemilikan KTP juga menjamin hak hak pemegangnya sebagai penduduk seperti yang diatur dalam peraturan perundang undangan yang berlaku.

b. KTP berfungsi sebagai identitas diri (kartu pengenal) yang umum diterima di instansi manapun. KTP umumnya merupakam salah satu bukti atau surat yang diminta oleh petugas keimigrasian, aparat kepolisian, petugas operasi yustisial kependudukan, pegawai bank (untuk transaksi perbankan), pejabat pemerintah dari ketua RT sampai desa dan kecamatan, serta pemilik rumah yang akan kita huni (sewa). Misalnya, Tanpa KTP, mustahil kita bisa membeli kendaraan atas nama kita.

c. Sebagai bukti bahwa kita sudah dianggap dewasa untuk melakukan berbagai macam tindakan, seperti membuka rekening di bank, menggandakan transaksi jual beli, sewa menyewa, peminjaman barang, dan pembuatan SIM.

2. Kegunaan KTP (Kartu Tanda Penduduk)

a. Bukti kependudukan untuk mendapatkan identitas diri lainnya, seperti paspor, akta perkawinan, dan bukti kepemilikan kendaraan bermotor.

b. Untuk kelengkapan melamar kerjaan, menikah, dan bercerai.

c. Untuk mendapatkan hak pilih dalam pelaksanaan pemilihan umum (pemilu).

3. Dasar Hukum Pembuatan KTP (Kartu Tanda Penduduk)

Dasar hukum yang menjadi acuan dalam kepemilikan dan pembuatan KTP adalah Kepres No. 52 Tahun 1977 tentang pendaftaran penduduk. Selanjutnya setiap daerah biasanya mempunyai ketentuan sendiri tentang peraturan pembuatan KTP. Sebagai contoh, di Kota Depok, Jawa Barat, diatur dengan Perda No. 38 Tahun 2008 (Lembaran Daerah No. 41 Tahun 2000) tentang Retribusi Penggantian Biaya Cetak Kartu Tanda Penduduk dan Akta Catatan Sipil.

4. Persyaratan Administratif KTP (Kartu Tanda Penduduk)

a. Surat pengantar dari RT dan RW setempat.

b. Salinan KK

c. Pas foto ukuran 2 × $3 \mathrm{~cm}$ sebanyak dua lembar

d. Akta kelahiran/surat kelahiran

e. KTP lama yang asli (untuk perpanjangan)

f. Salinan KTP dan bukti lapor kehilangan dari kepolisian (jika KTP hilang).

\subsection{Android}

Sherief Salbino S.Kom dalam [5] Android merupakan sistem operasi berbasis Linux yang bersifat terbuka (open source) dan dirancang untuk perangkat seluler layer sentuh seperti smartphone dan komputer tablet.

\subsection{Sejarah Android}

Sejarah singkat Android berawal pada saat Google Inc. membeli Android Inc. yang merupakan pendatang baru yang membuat peranti lunak untuk ponsel atau smartphone. Kemudian untuk mengembangkan Android, dibentuklah Open Handset Alliance, konsorsium dari 34 perusahaan peranti keras, peranti lunak dan telekomunikasi, termasuk Google, HTC, Intel, Motorola, Qualcomm, T-Mobile, dan Nvidia. Pada saat perilisan perdana Android, 5 November 2007, Android bersama Open Handset Alliance menyatakan mendukung pengembangan open source pada perangkat mobile. Di lain pihak, Google merilis kode-kode Android di bawah lisensi Apache, sebuah lisensi perangkat lunak dan open platform perangkat seluler[6]. 


\subsection{ADT (Android Developer Tools)}

Android Development Tools (ADT) adalah plug-in yang didesain untuk IDE Eclipse yang memberi kita kemudahan dalam mengembangkan aplikasi Android dengan menggunakan IDE Eclipse[7].

\subsection{Eclipse}

Eclipse adalah sebuah IDE (Integrated Development Environment) untuk mengembangkan perangkat lunak dan dapat dijalankan di semua platform (platform-independent)[8].

\subsection{JDK (Java Development Kit)}

Menurut Sun dalam [9] Java adalah nama untuk sekumpulan teknologi untuk membuat dan menjalankan perangkat lunak pada computer standalone ataupun pada lingkungan jaringan. Untuk membuat program Java dibutuhkan kompiler dan interpreter untuk program Java berbentuk Java Development Kit (JDK) yang diproduksi oleh Sun Microsystems.

\subsection{PHP (Hypertext Preprocessor)}

Bahasa pemrograman PHP merupakan bahasa pemrograman untuk mebuat web yang bersifat server-side scripting. PHP memungkinkan kita untuk membuat halaman web yang bersifat dinamis. PHP dapat dijalankan pada berbagai macam Operating System (OS), misalnya Windows, Linux dan Mac OS. Selain Apache, PHP juga mendukung beberapa web server lain, misalnya Microsoft IIS, Caudium, PWS dan lainlain. Seperti pernah disinggung sebelumnya bahwa PHP dapat memanfaatkan database untuk menghasilkan halaman web yang dinamis[10].

2.10 MySQL (My Structure Query Language)

MySQL (My Structure Query Language) adalah sebuah perangkat lunak sistem manajemen basis data $S Q L$, (Database Management System) atau DBMS dari sekian banyak DBMS, seperti Oracle, MS SQL, Postagre $S Q L$, dan lain-lain. MySQL merupakan DBMS yang multithread, multi-user yang bersifat gratis di bawah lisensi GNU General Public Licence (GPL)[11].

\subsection{UML (Unified Modeling Language)}

Windu Gata, Grace dalam [12] Unified Modeling Language (UML) adalah bahasa spesifikasi standar yang dipergunakan untuk mendokumentasikan, menspesifikasikan dan membanngun perangkat lunak. UML merupakan metodologi dalam mengembangkan sistem berorientasi objek dan juga merupakan alat untuk mendukung pengembangan system.

\section{METODE PENELITIAN}

\subsection{Metode Pengumpulan Data}

Dalam [13] ada beberapa teori yang dapat dilakukan dalam pengumpulan data yaitu :

1. Metode Penelitian Lapangan (Field Research)

Suatu metode penelitian yang digunakan secara langsung dalam penelitian yang berguna untuk mengumpulkan data. Adapun metode yang digunakan sebagai berikut :

a. Wawancara (Interview)

Metode yang digunakan dengan melakukan tanya jawab dengan para wisatawan sehingga dapat menghasilkan data dan informasi yang dibutuhkan dalam perancangan sistem .

b. Observasi (Pengamatan)

Metode yang digunakan dengan melakukan pengamatan secara langsung pada objek wisata yang bertujuan untuk menghasilkan data dan informasi yang dibutuhkan dalam perancangan sistem, agar dapat mengetahui hal-hal yang terjadi dilapangan.

2. Metode Penelitian Kepustakaan (Library Research)

Suatu metode penelitian yaitu metode pengumpulan data dengan mempelajari buku-buku yang berkaitan dengan masalah yang sedang dihadapi dalam penelitian, misalnya buku pemrograman android, buku pengembangan sistem informasi, dan lain-lain.

\subsection{Metode Perancangan Sistem}

Metode perancangan sistem adalah suatu perencanaan, penggambaran, dan pembuatan sistem dari beberapa elemen yang terpisah kedalam satu kesatuan yang utuh dan berfungsi. Perancangan sistem menentukan bagaimana sistem direncanakan, didesain, dan dibangun sedemikian rupa. Tahap perancangan sistem merupakan tahap lanjutan dalam pengembangan sistem informasi yang dilakukan setelah melakukan analisis sistem yang bertujuan untuk memberikan gambaran kepada user tentang bagaimana sistem baru yang diusulkan akan berkerja.

\subsection{Metode Waterfall}

Metode waterfall merupakan model pengembangan sistem informasi yang sistematik dan sekuensial [14]. Metode waterfall memiliki tahapan-tahapan sebagai berikut :

1. Requirements analysis and definition

Layanan sistem, kendala, dan tujuan ditetapkan oleh hasil konsultasi dengan pengguna yang kemudian didefinisikan secara rinci dan berfungsi sebagai spesifikasi sistem. 
2. System and software design

Tahapan perancangan sistem mengalokasikan kebutuhan-kebutuhan sistem baik perangkat kerasmaupun perangkat lunak dengan membentuk arsitektur sistem secara keseluruhan. Perancangan perangkat lunak melibatkan identifikasi dan penggambaran abstraksi sistem dasar perangkat lunak dan hubungannya.

3. Implementation and unit testing

Pada tahap ini, perancangan perangkat lunak direalisasikan sebagai serangkaian program atau unit program. Pengujian melibatkan verifikasi bahwa setiap unit memenuhi spesifikasinya.

4. Integration and system testing

Unit-unit individu program atau program digabung dan diuji sebagai sebuah sistem lengkap untuk memastikan apakah sesuai dengan kebutuhan perangkat lunak atau tidak. Setelah pengujian, perangkat lunak dapat dikirimkan ke customer

5. Operation and maintenance

Biasanya (walaupun tidak selalu), tahapan ini merupakan tahapan yang paling panjang. Sistem dipasang dan digunakan secara nyata. Maintenance melibatkan pembetulan kesalahan yang tidak ditemukan pada tahapan-tahapan sebelumnya, meningkatkan implementasi dari unit sistem, dan meningkatkan layanan sistem sebagai kebutuhan baru.

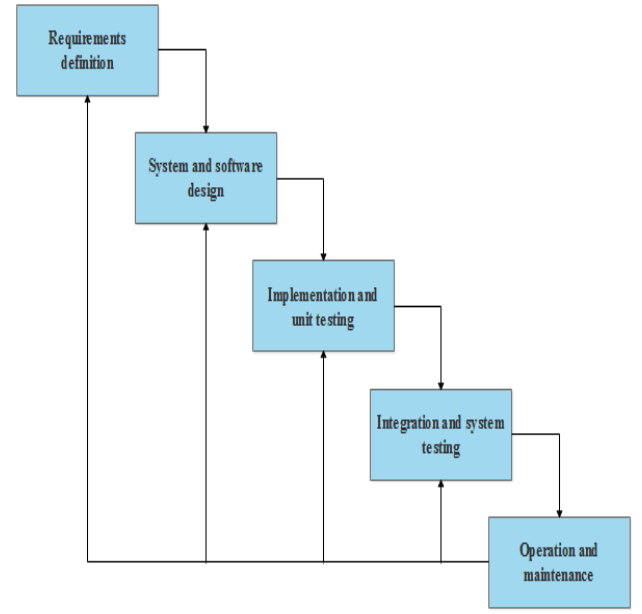

Gambar 1. Metode Waterfall

\subsection{Metode Perancangan Sistem}

Dalam pembuatan sistem alat yang digunakan dalam membuat perancangan dan desain sistem informasi bahasa pemandu wisata yaitu dengan menggunakan Unified Modeling Language (UML).

\subsubsection{Use Case Diagram}

Use case diagram merupakan fungsionalitas yang disediakan sistem sebagai unit-unit yang saling bertukar pesan antar unit atau actor [15]. Use case diagram dalam aplikasi formulir KTP (Kartu Tanda Penduduk) yaitu :

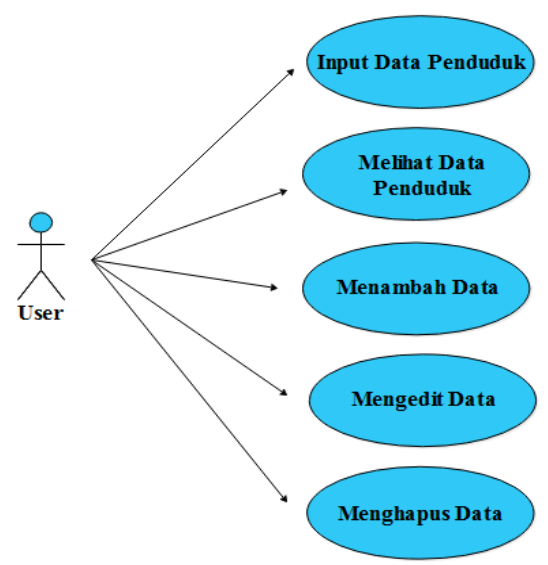

Gambar 2. Use Case Diagram 


\subsubsection{Activity Diagram}

Activity diagram adalah memodelkan alur kerja (workflow) sebuah proses bisnis dan urutan aktivitas dalam suatu proses [16]. Activity diagram dalam aplikasi formulir KTP (Kartu Tanda Penduduk) yaitu :

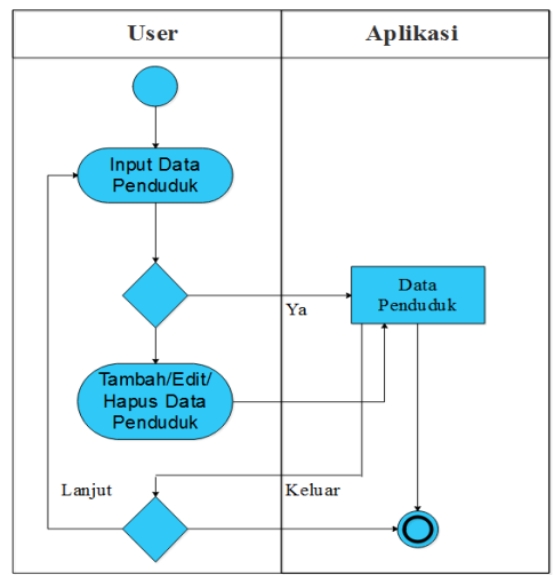

Gambar 3. Activity Diagram

\subsubsection{Sequence Diagram}

Sequence diagram adalah suatu diagram interaksi yang menekankan pada pengaturan waktu dari pesan-pesan [17]. Sequence diagram dalam aplikasi formulir KTP (kartu tanda penduduk) yaitu :

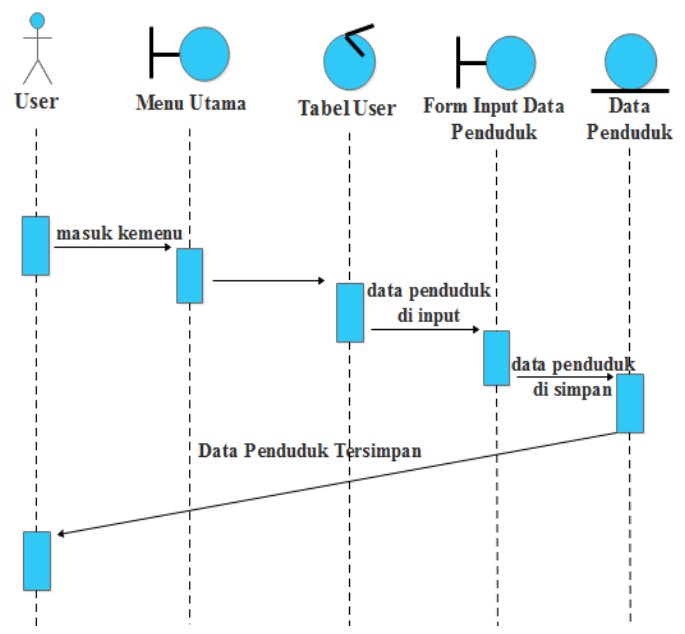

Gambar 5. Sequence Diagram

Aplikasi ini telah dihubungkan dengan database dalam satu jaringan handphone sehingga dapat menampilkan data penduduk yang telah di-inputkan pada aplikasi Formulir KTP berbasis android. Rancangan sistem diperoleh hasil berupa aplikasi yang berisikan tampilan dari program meliputi tampilan icon, splash screen, tampilan keseluruhan aplikasi, tampilan tambah data penduduk, tampilan edit/delete dan tampilan update. Pada tahap ini akan dijelaskan hasil bagian dari semua fungsi yang ada pada aplikasi seperti tampilan splash screen, tambah data penduduk (berisi data yang harus diinputkan oleh user seperti Nomor Registrasi, Provinsi, Kabupaten, Kecamatan, Kelurahan, Nama Lengkap, No.KK, Alamat, RT, RW dan Kode Pos), edit/delete (aksi untuk meng-edit dan menghapus data) dan update (aksi untuk meng-update data atau memperbaharui data).

\subsubsection{Tampilan Icon Aplikasi Formulir KTP}

Tampilan icon merupakan tampilan awal pada aplikasi Formulir KTP, disini user atau masyarakat harus mengklik icon aplikasi Formulir KTP berbasis android untuk masuk ke tampilan berikutnya.

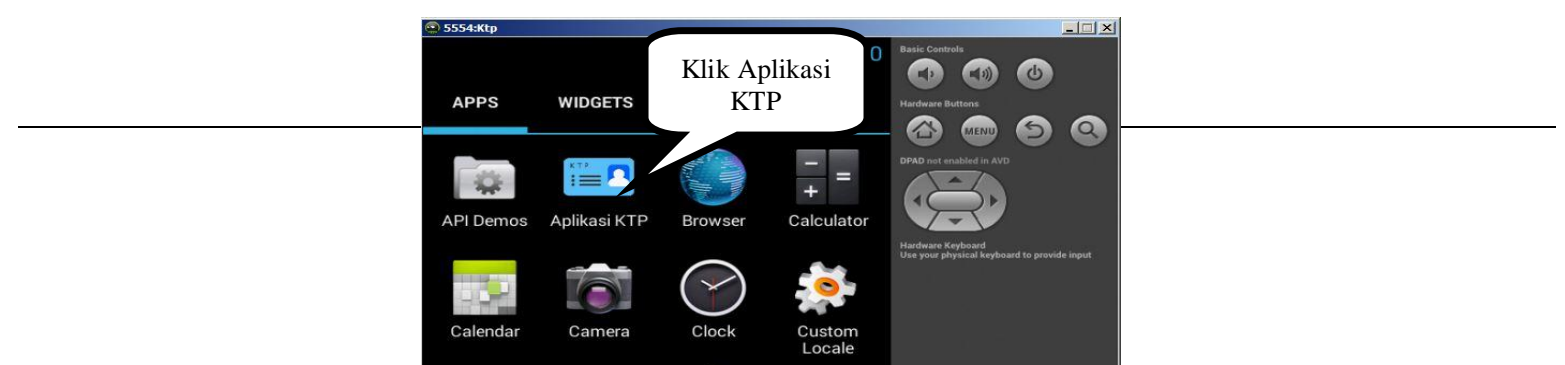


Gambar 5. Tampilan Icon

\section{Tampilan Splash Screen}

Tampilan ini akan menampilkan tampilan splash screen aplikasi Formulir KTP yang berisi gambar dari Kantor Camat Rantau Utara. Berikut tampilan splash screen dalam aplikasi Formulir KTP berbasis android :

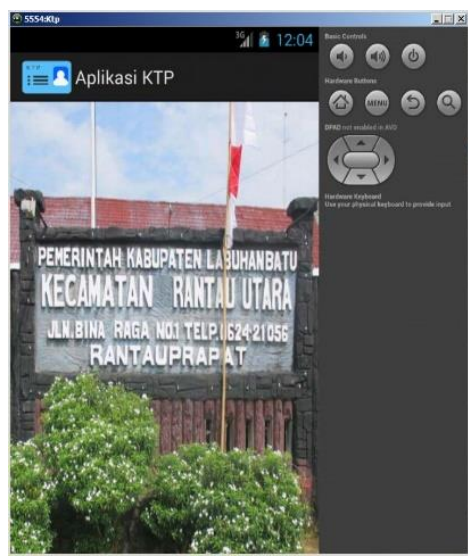

Tampilan Aplikasi

Gambar 6. Tampilan Splash Screen

Tampilan aplikasi merupakan tampilan keseluruhan meliputi semua tampilan yang ada di dalam aplikasi Formulir KTP berbasis android.

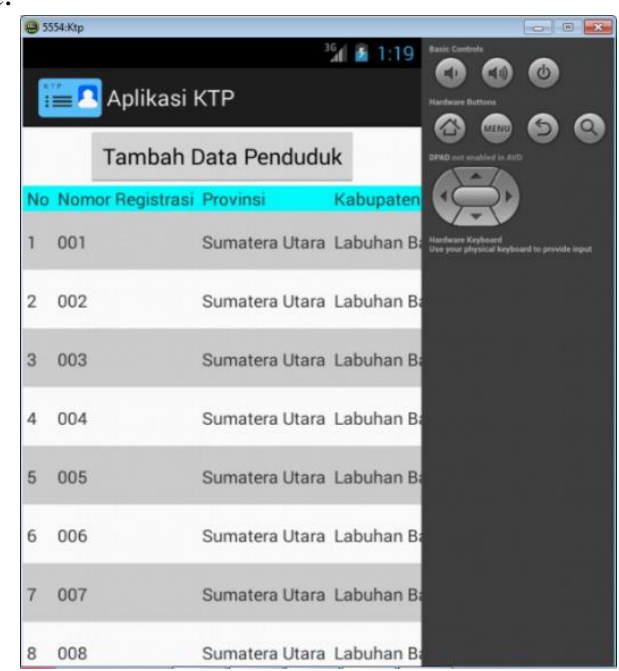

Gambar 7. Tampilan Aplikasi 


\section{Tampilan Tambah Data Penduduk}

Tampilan tambah data penduduk merupakan sebuah aksi yang harus dilakukan oleh user atau masyarakat, agar dapat menginputkan data penduduk user harus mengklik tombol tambah data penduduk pada aplikasi Formulir KTP berbasis android.

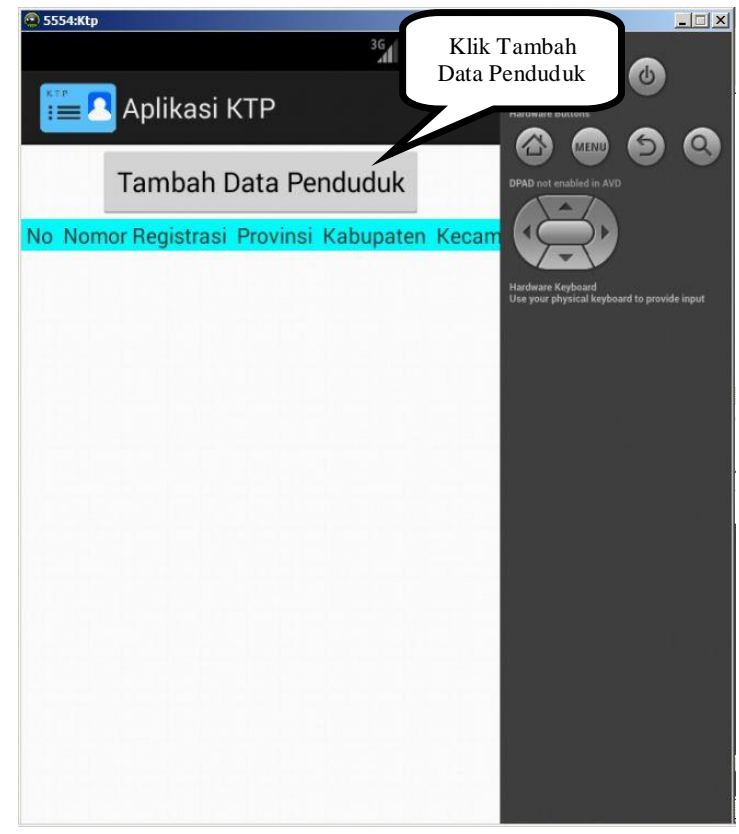

Gambar 8. Tampilan Tambah Data Penduduk

\section{Tampilan Form Input Data Penduduk}

Pada form input data penduduk pada aplikasi Formulir KTP merupakan aksi yang dilakukan oleh user untuk memasukkan data penduduk dengan cara, user harus mengklik tombol tambah data penduduk, setelah itu baru user dapat meng-inputkan data penduduk berupa Nomor Registrasi, Provinsi, Kabupaten, Kecamatan, Kelurahan, Nama Lengkap, No.KK, Alamat, RT, RW dan Kode Pos. Setelah semua di lengkapi kemudian klik insert lalu akan muncul pemberitahuan "Data Berhasil Disimpan", secara otomatis data penduduk yang di-inputkan akan masuk ke database dan akan langsung menampilkan data penduduk.

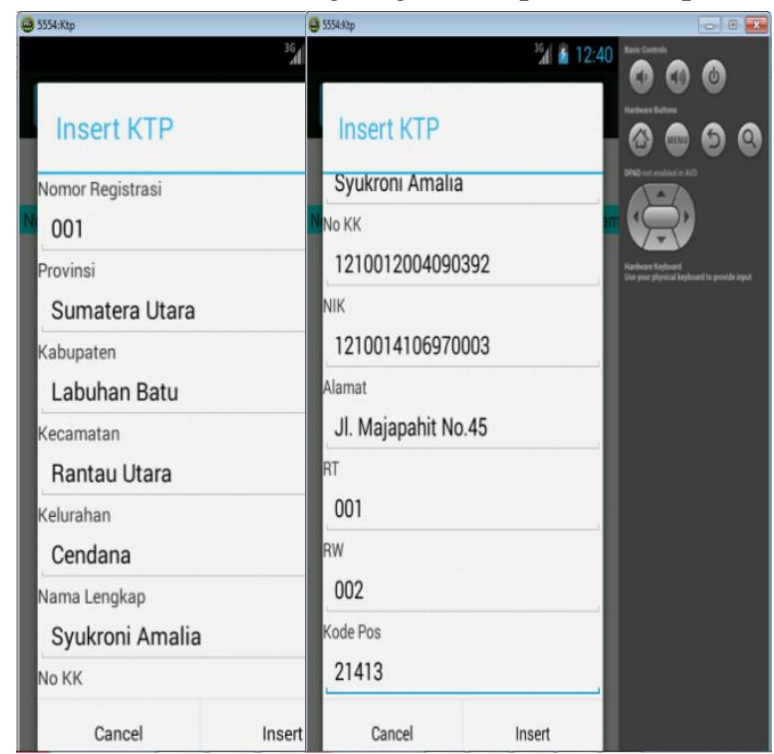

Gambar 9. Tampilan Form Input Data Penduduk 


\section{Tampilan Hasil (Output)}

Pada tampilan hasil, user atau masyarakat dapat langsung melihat data penduduk yang telah di-inputkan. Disini user dapat melakukan aksi yaitu edit dan delete. Aksi Edit dilakukan jika ada kesalahan pada saat meng-inputkan data dan aksi delete. dilakukan untuk menghapus data.

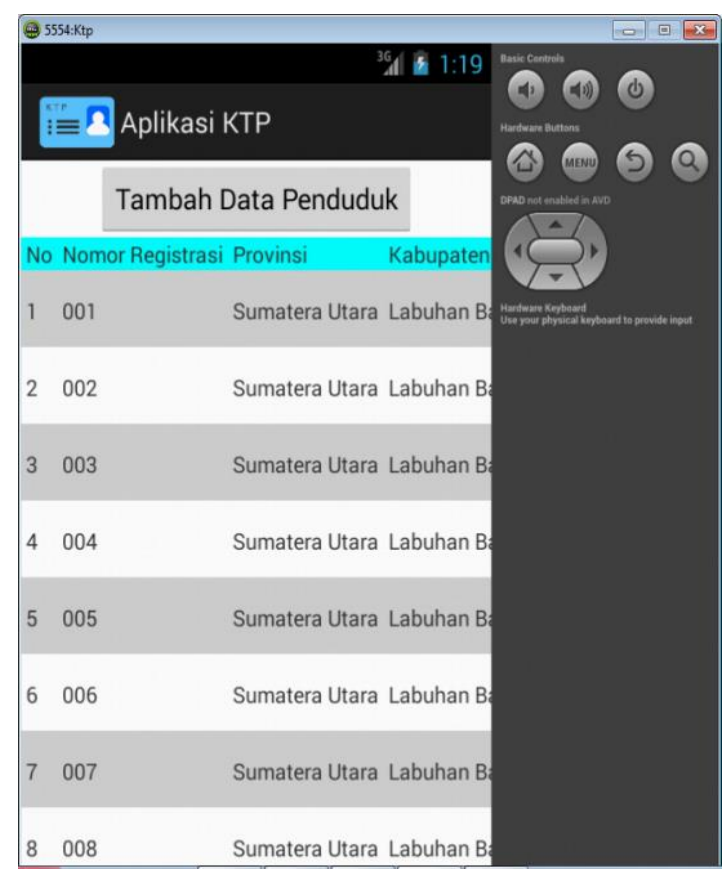

Gambar 10. Tampilan Hasil (Output)

\section{Tampilan Edit/Delete}

Tampilan edit/delete merupakan sebuah aksi yang dilakukan oleh user atau masyarakat untuk meng-edit atau menghapus data penduduk apabila terjadi kesalahan pada saat meng-inputkan data. Jika user mengklik tombol edit maka akan tampil form update dan jika user mengklik tombol delete maka akan muncul pemberitahuan "Delete Data Berhasil" pada aplikasi Formulir KTP berbasis android.

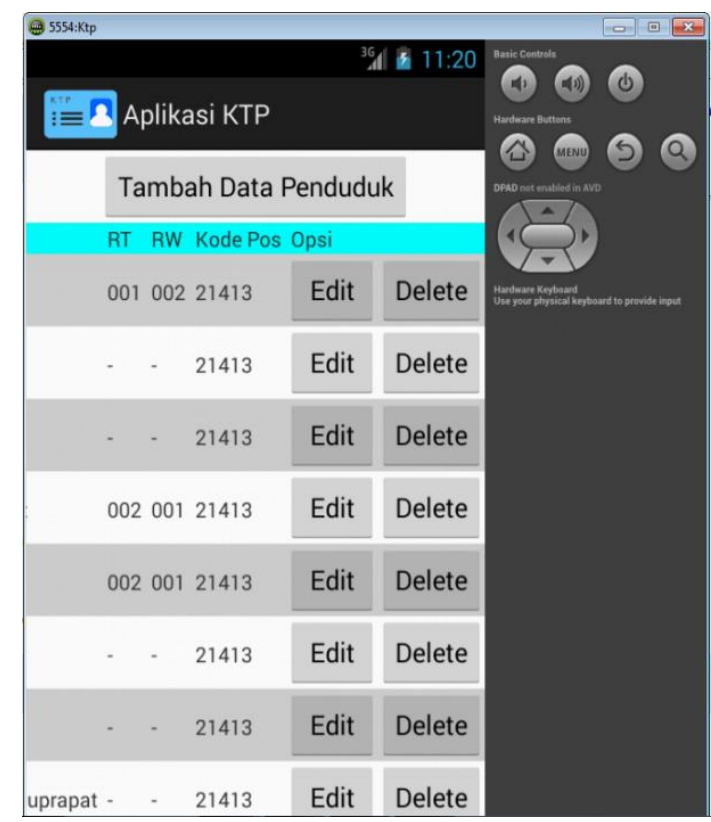

Gambar 10. Tampilan Edit/Delete 


\section{Tampilan Form Update Data Penduduk}

Tampilan form update data penduduk merupakan sebuah aksi yang dilakukan oleh user atau masyarakat untuk meng-update data penduduk apabila terjadi kesalahan pada saat meng-inputkan data atau data yang telah dimasukkan ingin diubah, dan tampilan update akan tampil setelah user mengklik tombol edit. Setelah tampil dan data diubah maka klik tombol update maka akan muncul pemberitahuan "Update Data Berhasil" pada aplikasi Formulir KTP berbasis android.

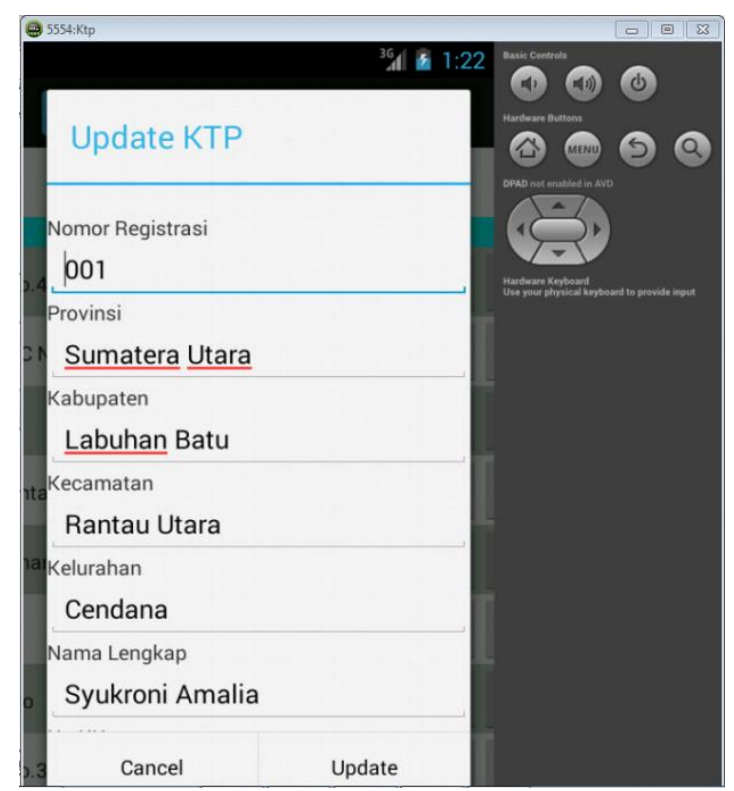

Gambar 11. Tampilan Form Update Data Penduduk

\section{Prosedur Kerja Sistem}

Prosedur kerja sistem yang terdapat pada aplikasi Formulir KTP berbasis android dimulai dengan user mengklik icon aplikasi. Aplikasi akan memunculkan tampilan splash screen, selanjutnya user dapat mengklik tombol tambah data untuk meng-inputkan data penduduk (seperti Nomor Registrasi, Provinsi, Kabupaten, Kecamatan, Kelurahan, Nama Lengkap, No.KK, Alamat, RT, RW dan Kode Pos), dan setelah selesai user dapat mengklik tombol insert dan akan muncul pemberitahuan "Data Berhasil Disismpan” setelah itu user dapat langsung melihat data penduduk yang telah masuk.

Apabila user ingin meng-edit ataupun menghapus data penduduk maka user memilih tombol edit/delete pada aplikasi yang letaknya berada setelah .kolom kode pos yaitu kolom opsi. Jika user mengklik tombol edit maka akan tampilan form update pada tampilan tersebut user dapat mengubah data dan setelah diubah dapat mengklik tombol update dan akan muncul pemberitahuan "Update Data Berhasil" dan jika anda mengklik tombol delete maka user akan menghapus data setelah diklik maka akan muncul pemberitahuan "Delete Data Berhasil".

\section{KESIMPULAN}

Dari pembahasan mengenai aplikasi Formulir KTP berbasis android maka dapat disimpulkan bahwa :

1. Dengan adanya aplikasi Formulir KTP berbasis android ini, maka proses peng-inputan data penduduk dapat dilakukan dengan cepat dan efesiensi tanpa harus ke kantor untuk mengisi formulir KTP tersebut.

2. Dengan adanya aplikasi Formulir KTP berbasis android ini, pelayanan dan pembuatan KTP (Kartu Tanda Penduduk) dapat lebih mudah dan cepat.

3. Pengolahan data penduduk pada aplikasi Formulir KTP berbasis android ini akan memudahkan proses kerja sehingga dapat meningkatkan kinerja instansi nantinya.

4. Telah dibangun sebuah aplikasi Formulir KTP berbasis android yang dirancang dengan menggunakan UML (Unified Modelling Language) dan diimplementasikan menggunakan eclipse untuk aplikasi android menggunakan bahasa pemrograman $P H P$ dan MySQL dan untuk database-nya secara online dalam satu jaringan.

\section{REFERENSI}

[1] M. D. Zericka, "Pengembangan Informasi Di Kabupaten Kutai Kartanegara," eJournal Ilmu Komun., vol. 1, no. 1, pp. 345-361, 2013.

[2] R. Habibie, R. R. Isnanto, and R. Kridalukmana, “Aplikasi Data Pelanggan Berbasis Java Dan 
Mobile Pada PT.PLn(PERSERO) Area Semarang,” J. Teknol. dan Sist. Komput., vol. 4, no. 1, pp. 50-59, 2016.

[3] W. P. Rahayu and K. K. Saptorini, "Pengetahuan Dan Sikap Perawat Rawat Inap Terhadap Pengisian Formulir Resume Asuhan Keperawatan (RM 13) Di RS. Permata Medika Semarang Tahun 2015," no. Rm 13, 2015.

[4] D. Prihastini, "Sistem Informasi Pelayanan Kependudukan," 2014.

[5] Salbino, Sherief. S.Kom.(2014) 'Buku Pintar Gadget Android', 1, Jakarta, Kunci Komunikasi.

[6] A. Juansyah, "Pembangunan Aplikasi Child Tracker Berbasis Assisted-Global Positioning System(A-GPS) Dengan Platform Android,” J. Ilm. Komput. dan Inform., vol. 1, no. 1, 2015.

[7] H. Kusniyati and N. S. P. Sitanggang, "Aplikasi Edukasi Budaya Toba Samosir Berbasis Android," J. Tek. Inform., vol. 9, no. 1, pp. 9-18, 2016.

[8] Sulihati and Andriyani, “Aplikasi Akademik Online Berbasis Mobile Android Pada Universita Tama Jagakarsa,” J. SAINS DAN Teknol., vol. XI, no. 152, 2016.

[9] D. M. I. Armida, P. Aji, and S. D. Budiwati, "Aplikasi Panduan Pembayaran Pajak Kendaraan Berbasis Android," vol. 2, no. 1, pp. 122-131, 2016.

[10] A. Hendini, "Pemodelan UML Sistem Informasi Monitoring Penjualan Dan Stok Barang," $J$. KHATULISTIWA Inform., vol. IV, no. 2, pp. 107-116, 2016.

[11] G. W. Sasmito, "Penerapan Metode Waterfall Pada Desain Sistem Informasi Geografis Industri Kabupaten Tegal,” vol. 2, no. 1, pp. 6-12, 2017.

\section{BIBLIOGRAFI PENULIS}

\begin{tabular}{|l|l|}
\hline & $\begin{array}{l}\text { Selvi Silestian } \\
\text { Computer Intermediate Expert, AMIK (Academy of Computer Informatics } \\
\text { Management), Foundation of Labuhanbatu University, Rantauprapat } 2018 . \\
\text { Email : selvisilestian97@ gmail.com }\end{array}$ \\
\hline & $\begin{array}{l}\text { Sumitro } \\
\text { Sumitro.ulb@gmail.com }\end{array}$ \\
\hline & $\begin{array}{l}\text { Iwan Purnama } \\
\text { Master Computer, UPI YPTK (University of Putera Indonesia Foundation Computer } \\
\text { College), Padang 2016, Lecturer at AMIK Labuhan Batu. } \\
\text { Email : iwanpurnama2014@ gmail.com }\end{array}$ \\
\hline
\end{tabular}

